\title{
Een hecht team als steun in tijd van crisis
}

In onzekere en stressvolle omstandigheden, zoals de coronapandemie, is psychosociale ondersteuning van zorgpersoneel essentieel. Nu hiervoor richtlijnen worden ontwikkeld, hebben de auteurs een quickscan uitgevoerd naar de behoeften van verpleegkundigen.

auteurs

FIEKE BRUGGEMAN

onderzoeker/

beleidsadviseur ARQ

Kenniscentrum Impact van Rampen en Crises

HANS TE BRAKE

senior onderzoeker/

beleidsadviseur ARQ

Kenniscentrum Impact van

Rampen en Crises

RENÉE DIJKHUIS

onderzoeker/

beleidsadviseur ARQ

Kenniscentrum Impact van

Rampen en Crises

\section{MONIQUE VAN DIJK hoogleraar \\ Verplegingswetenschap Erasmus MC}

BIANCA BUURMAN

hoogleraar en lector Acute

Ouderenzorg UvA/

Amsterdam UMC/

Hogeschool van

Amsterdam, voorzitter

V\&VN, bestuurslid ZWiC

ANNE DE PAGTER

kinderhematoloog Erasmus MC/LUMC, bestuurslid ZWiC
D E CORONAPANDEMIE HEEFT

ertoe geleid dat verpleegkundigen werken in onzekere en stressvolle omstandigheden. ${ }^{1-2}$ Goede ondersteuning van zorgprofessionals is belangrijk voor optimale vitaliteit en werkplezier. ${ }^{3}$ Er zijn verschillende initiatieven om verpleegkundigen te ondersteunen op de werkvloer, maar hierover is nog weinig kennisuitwisseling.

Op basis van behoeftes op de werkvloer wordt in opdracht van Stichting Zorg na Werken in Coronazorg (ZWiC) een richtlijn ontwikkeld voor optimale psychosociale ondersteuning van zorgpersoneel. Dit zal worden uitgevoerd door ARQ Kenniscentrum Impact van Rampen en Crises, dat eerder een dergelijke richtlijn ontwikkelde voor hoog-risicoberoepen, zoals politie, ambulance, brandweer en defensie. ${ }^{4}$ In aanloop naar de richtlijn voor zorgprofessionals hebben wij een quickscan uitgevoerd naar de ondersteuningsbehoeften van verpleegkundigen. Ook vroegen we naar de ervaringen met enkele veelgebruikte ondersteuningsvormen, zoals peer support, moreel beraad en mental checkupgesprekken.

\section{QuickScan}

Zes zorgorganisaties zijn benaderd. Ze vertegenwoordigen verschillende sectoren waar directe zorg aan coronapatiënten wordt geleverd: een algemeen zieken- huis (HagaZiekenhuis, interne geneeskunde), drie academische ziekenhuizen (Erasmus MC, IC en COVID19-afdeling; Amsterdam UMC, hematologieafdeling; UMC Utrecht, spoedeisende hulp), een ouderenzorginstelling (Het Parkhuis) en een thuiszorginstelling (Buurtzorg). Het betreft een gelegenheidsselectie, waarbij is geprobeerd om behalve verschillende sectoren ook diverse ondersteuningsvormen te betrekken.

Binnen elke organisatie zijn een manager en verpleegkundige geïnterviewd. In de 12 semigestructureerde interviews hebben we gevraagd we hoe je als verpleegkundige op de been blijft in deze crisissituatie en hoe ondersteuningsvormen daaraan kunnen bijdragen. Hieruit kwamen vier adviezen naar voren voor ondersteuning van verpleegkundigen (zie kadertekst pag. 34).

De interviews (gemiddelde duur $50 \mathrm{mi}$ nuten) vonden plaats via videobellen, werden opgenomen en door de interviewer (FB) samengevat en ter feitelijke controle voorgelegd aan de geïnterviewde (memberchecking). ${ }^{5}$ De samenvattingen werden naast elkaar gelegd en geanalyseerd. In tabel 1 is weergegeven welke ondersteuningsvormen aan de orde kwamen tijdens de interviews.

\section{Wat houdt je op de been?}

Waar managers zich vooral richten op het 
gevoel krijgen dat er over hen heen wordt geregeerd doordat protocollen gewijzigd worden. De hoge werkdruk leidt tot vermoeidheid, chaos en frustraties. Alle energie wordt gestoken in patiëntenzorg en er blijft weinig energie over om te zorgen voor jezelf, maar ook voor elkaar. Tijd en kracht om na te bespreken (en dus: iets te verbeteren) ontbreken na een lange dag werken.

\section{Ondersteuningsvormen}

De geïnterviewden noemden dat het gezamenlijk bespreken van het werk en de samenwerking een mogelijkheid kan bieden om van perspectief te wisselen. Te denken valt aan peer support in teamverband, dagsluitingen of intervisie begeleid door een coach. Deze ondersteuningsvormen leiden tot onderlinge steun en begrip en een betere samenwerking. Het doorvragen naar elkaars beleving kan een manier bieden om stoom af te blazen. Er kan ook worden geleerd: wat gaat goed, wat kan beter? Ondanks enige weerstand om stil te staan bij hoe het nu met je is ('Wij verpleegkundigen hebben gekozen voor dit beroep, dat soort gesprekken heb ik niet nodig'), zeiden verpleegkundigen dat het prettig is hiervoor de tijd te nemen met elkaar ('Ik wist niet dat het me zoveel kon brengen'). Een ondersteuningsvorm als moreel beraad biedt daarnaast expliciet de ruimte om met verschillende disciplines te reflecteren op wat wordt verstaan onder goede zorg. Dit draagt bij aan professionele groei.

Individuele ondersteuning, zoals één-opéén-gesprekken met bijvoorbeeld een peer supporter of coach, biedt de mogelijkheid te reflecteren op het eigen handelen en na een incident vertrouwen terug te krijgen. Ook kan een mental check-upgesprek inzage geven in wat een verpleegkundige zelf kan doen om mentaal fit te blijven. Een hulplijn (via telefoon of e-mail) biedt een laagdrempelige vorm van ondersteuning. Ondersteuningsvormen kunnen bovendien bijdragen aan het tijdig signaleren van problemen en, indien nodig, leiden tot verwijzing naar meer professionele hulpverlening.

\section{Het hechte team als de kern}

De resultaten van deze quickscan geven

gevoel van gedeelde verantwoordelijkheid voor de geleverde zorg. Het gaat gepaard met oog voor elkaar hebben en openlijk met elkaar delen hoe het met je gaat. Een verpleegkundige gebruikte het woord 'familiair' om haar team te beschrijven. Het onder intensieve omstandigheden samenwerken maakt dat je het gauw genoeg merkt als een collega niet lekker in zijn of haar vel zit. Behalve directe collega's hebben leidinggevenden een belangrijke taak in het signaleren en bieden van een luisterend oor. De meeste problemen blijken in het team zelf opgelost te worden. Slechts incidenteel is een gesprek met een coach of psycholoog nodig.

\section{Hechtheid onder druk}

Bij teams die zeer getroffen zijn door de coronacrisis - sommige geïnterviewden spraken over 'een trauma in het team' - is het juist de hechtheid, de familiariteit, die onder druk komt te staan. Teams wijzigen vanwege zieke en re-integrerende verpleegkundigen en de instroom van collega's van andere afdelingen. Ook de invoering van cohortverpleging staat de onderlinge samenhang in de weg. Daarnaast kunnen verpleegkundigen het

\section{TABEL 1 OVERZICHT VAN ONDERSTEUNINGSVORMEN}

\begin{tabular}{|c|c|c|}
\hline Organisatie & Ondersteuningsvorm & Omschrijving \\
\hline $\begin{array}{l}\text { Erasmus MC, Utrecht } \\
\text { UMC }\end{array}$ & $\begin{array}{l}\text { Peer support } \\
\text { individueel }\end{array}$ & $\begin{array}{l}\text { 1-op-1 gesprek met een ervaren zorgverlener die werkzaam } \\
\text { is in dezelfde organisatie (maar niet binnen hetzelfde team) } \\
\text { en is opgeleid tot peer-supporter. }\end{array}$ \\
\hline UMC Utrecht & Peer support-groep & $\begin{array}{l}\text { Groepsgesprekken op aanvraag, begeleid door verpleegkun- } \\
\text { digen van de eigen afdeling. }\end{array}$ \\
\hline Amsterdam UMC & Moreel beraad & $\begin{array}{l}\text { Ethiekondersteuning in groepsverband begeleid door een } \\
\text { ethicus. Een moreel dilemma wordt behandeld met alle } \\
\text { betrokkenen (dus ook andere medische disciplines). }\end{array}$ \\
\hline Amsterdam UMC & Wandelingen & $\begin{array}{l}\text { In tweetallen met extern begeleider (iemand van HR, een } \\
\text { geestelijk verzorger of gespreksleiders van moreel beraad). }\end{array}$ \\
\hline HagaZiekenhuis & Mental check-up & $\begin{array}{l}\text { 1-op-1 gesprek met een psycholoog waarin arbeidstevreden- } \\
\text { heid en psychische weerbaarheid worden geïnventariseerd. }\end{array}$ \\
\hline $\begin{array}{l}\text { Amsterdam UMC, } \\
\text { HagaZiekenhuis, Buurt- } \\
\text { zorg, Het Parkhuis }\end{array}$ & Hulplijn & $\begin{array}{l}\text { Via telefoon of e-mail informatie en support bieden (luiste- } \\
\text { rend oor, advisering, verwijzen naar psycholoog). }\end{array}$ \\
\hline Buurtzorg & Regiocoach & Beschikbaar voor begeleiding van het team indien nodig. \\
\hline $\begin{array}{l}\text { Erasmus MC, } \\
\text { HagaZiekenhuis, Het } \\
\text { Parkhuis, } \\
\text { Amsterdam UMC }\end{array}$ & $\begin{array}{l}\text { Psychosociaal } \\
\text { ondersteuner op de } \\
\text { afdeling }\end{array}$ & $\begin{array}{l}\text { Een coach, psycholoog, geestelijk verzorger, ethicus of } \\
\text { bedrijfsmaatschappelijk werker die kan worden geraad- } \\
\text { pleegd. }\end{array}$ \\
\hline \multirow[t]{2}{*}{ Alle organisaties } & $\begin{array}{l}\text { Teamvergaderingen, } \\
\text { dagelijkse bijeen- } \\
\text { komsten of intervisie }\end{array}$ & $\begin{array}{l}\text { Op aanvraag of op structurele basis. Eventueel begeleid door } \\
\text { de leidinggevende of psychosociaal ondersteuner. }\end{array}$ \\
\hline & $\begin{array}{l}\text { Ondersteuning via } \\
\text { intranet }\end{array}$ & $\begin{array}{l}\text { Informatievoorziening over protocollen (veiligheid, hygiëne), } \\
\text { scholing (werkinhoudelijk), cursussen en/of tools (bijvoor- } \\
\text { beeld mindfulness). }\end{array}$ \\
\hline
\end{tabular}


FIGUUR 1 KRINGENMODEL: GEFASEERDE ONDERSTEUNING VOOR MEDEWERKERS IN DE ZORG ${ }^{4,8}$

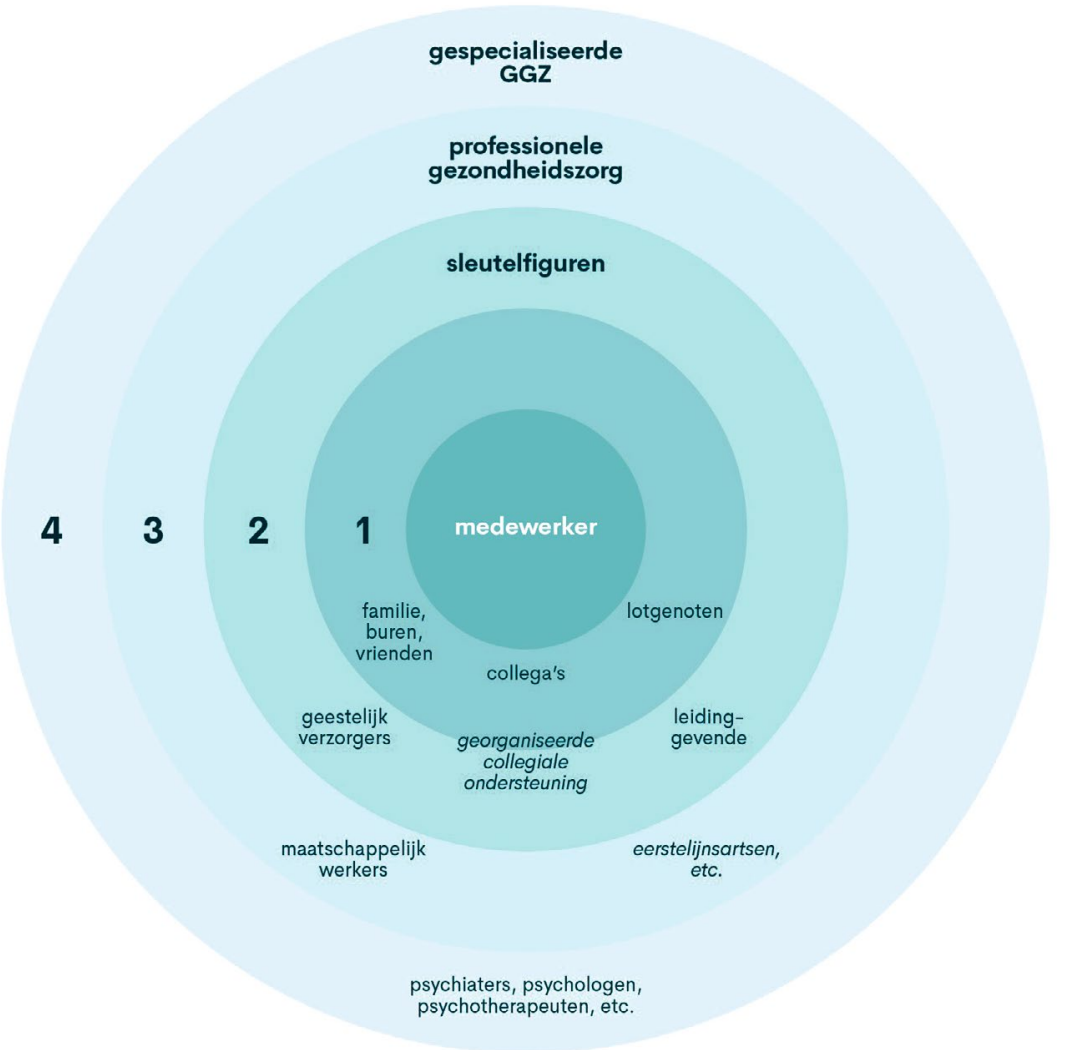

natuurlijk slechts een indruk. Niettemin komt een duidelijke boodschap naar voren: een hecht team - juist in crisis-

situaties - is essentieel voor behoud van vitaliteit en werkplezier. Daarnaast zijn andere zaken essentieel om zorgprofessi-

\section{Adviezen voor ondersteuning verpleegkundigen}

Advies 1: Zorg voor voldoende betrokkenheid, aandacht en waardering door het management. Het management moet zichtbaar zijn op de werkvloer en persoonlijke betrokkenheid tonen. Zoals een verpleegkundige zei: 'Letterlijk naast iemand staan geeft steun'. Het management moet ervoor zorgen op de hoogte te zijn van de behoeften op de werkvloer. Alleen dan kunnen besluiten passend en in gezamenlijkheid worden gemaakt.

Advies 2: Zorg voor goede organisatie van werk. Besteed aandacht aan informatievoorziening over (nieuwe) protocollen en de organisatie van werk, zodat er zoveel mogelijk duidelijkheid en rust op de werkvloer ontstaat. Een gezond rooster, waarbij voldoende ruimte is om te herstellen tussen de diensten, is essentieel. Hierdoor verlaagt de werkdruk, zodat verpleegkundigen energie hebben om elkaar te ondersteunen en om na te bespreken.

Advies 3: Maak nabespreken 'normaal'. Bespreek het werk en de samenwerking in het team. Maak het onderdeel van de routine; koppel intervisie bijvoorbeeld aan een klinische les. Creëer een veilig klimaat waarin problemen bespreekbaar zijn. Leer elkaar kennen, bijvoorbeeld door teambuildingsactiviteiten.

Advies 4: Bied laagdrempelige toegang tot professionele hulpverlening. Als de steun uit het eigen team en de directe context onvoldoende blijkt te zijn, is meer professionele hulpverlening nodig. Het moet duidelijk zijn hoe professionele hulpverlening gevonden kan worden.

onals op de been te houden: juiste informatievoorziening over nieuwe protocollen, een gezond rooster, nabespreken en laagdrempelig toegang bieden tot professionele hulpverlening. Dit sluit aan bij eerder verzamelde adviezen voor ondersteuning aan zorgprofessionals blootgesteld aan coronapatiënten. ${ }^{6-7}$ De geïnterviewden onderschrijven de voordelen van diverse ondersteuningsvormen, maar het is duidelijk dat die pas in tweede instantie in beeld komen: wanneer het team er zelf niet uitkomt. Deze bevindingen passen binnen het kringenmodel (zie figuur 1). Dit geeft schematisch weer dat de steun van de directe omgeving centraal staat en, als dat onvoldoende blijkt, stapsgewijs meer professionele hulpverlening kan worden ingezet. ${ }^{4,8}$ De quickscan maakt duidelijk dat voor de te ontwikkelen richtlijn voor optimale psychosociale ondersteuning van zorgprofessionals, de focus vooral moet liggen op de binnenste kringen van het model.

\section{REFERENTIES}

1. Danet Danet A. Psychological impact of COVID-19 pandemic in Western frontline healthcare professionals. A systematic review. Medicina Clinica. 2021;1.

2. Sheraton M, Deo N, Dutt T, e.a. Psychological effects of the COVID 19 pandemic on healthcare workers globally: A systematic review. Psychiatry Research. 2020;292.

3. Fiest KM, Parsons Leigh J, Krewulak KD, e.a. Experiences and management of physician psychological symptoms during infectious disease outbreaks: a rapid review. BMC Psychiatry. 2021;21(1).

4. Impact. Richtlijn psychosociale ondersteuning geüniformeerden. Diemen: $A R Q$ Kenniscentrum Impact van rampen en crises. 2012;29.

5. Birt L, Scott S, Cavers D, e.a. Member Checking: A Tool to Enhance Trustworthiness or Merely a Nod to Validation? Qualitative Health Research. 2016; 26(13):1802-1811. 6. Owens IT. Supporting nurses' mental health during the pandemic. Nursing. 2020; 50(10).

\section{Schoonhoven L, Trappenburg J \&}

Bleijenberg N. Co-fit rapport. Behoud van korte en lange termijn fysieke/mentale gezondheid en inzetbaarheid van zorgprofessionals blootgesteld aan COVID-19 crisis werkomstandigheden. UMC Utrecht - Julius Centrum Verplegingswetenschap/THINC. - Hogeschool Utrecht - Lectoraat Chronisch Zieken en Proactieve Ouderenzorg. 2020; 1-36.

8. Impact. Richtlijn psychosociale hulp bij rampen en crises. Diemen: $A R Q$ Kenniscentrum Impact van rampen en crises. 2014;26. 